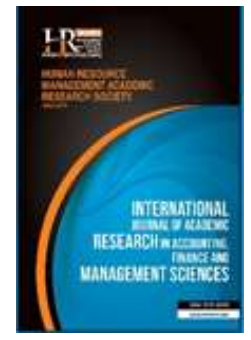

International Journal of Academic Research in Accounting, Finance and Management Sciences

Vol. 9, No.4, October 2019, pp. 285-293

E-ISSN: 2225-8329, P-ISSN: 2308-0337

(C) 2019 HRMARS

www.hrmars.com

To cite this article: Hikmayah, N., Aswar, K. (2019). The Impact of Factors on the Audit Quality in Indonesia: The Moderating Effect of Professional Commitments, International Journal of Academic Research in Accounting, Finance and Management Sciences 9 (4): 285-293

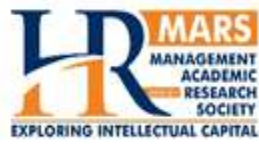

\title{
The Impact of Factors on the Audit Quality in Indonesia: The Moderating Effect of Professional Commitments
}

\author{
Nofiati Hikmayah ${ }^{1}$, Khoirul Aswar ${ }^{2}$ \\ ${ }^{1,2}$ Faculty of Economics and Business, Universitas Pembangunan Nasional Veteran Jakarta, Jl. RS Fatmawati, Pondok \\ Labu, Jakarta, ${ }^{1}$ E-mail: hikmayahn@gmail.com, ${ }^{2}$ E-mail: aswar_law@yahoo.com
}

\begin{abstract}
This research is conducted and deemed to determine the effect of professional accounting ethics, auditor competence and professional integrity and commitment to audit quality. In addition, this study aims to determine the effect of auditor competence and integrity auditor on audit quality that is moderated by professional commitment. The population in this study is Badan Pengawasan Keuangan dan Pembangunan (BPKP) of DKI Jakarta Province. Sampling is done by purposive sampling method with the criteria of government internal auditors who have taken study and training the JFA (Functional Auditor Functional) and has a minimum of 2 years work experience. The number of samples used in this study amounted to 62 samples of auditors working in Badan Pengawasan Keuangan dan Pembangunan (BPKP) of DKI Jakarta Province. The analysis technique used is Structural Equation Modeling (SEM) using the application Smart Partial Least Square version 3.0. The results of this study indicate that professional accounting ethics and integrity have a significant effect on audit quality. Auditor competency and professional commitment are not significant to audit quality. Professional commitment moderates the influence of the relationship between integrity and audit quality and influences the negative effect. Professional commitment does not moderate the effect of the relationship between auditor competence and audit quality. The contribution given to the BPKP of DKI Jakarta Province is that there is a need for an authoritative, orderly and wellregulated supervisory apparatus in carrying out the duties and functions of the government's internal auditors in accordance with the APIP code of ethics and APIP audit standards.
\end{abstract}

Key words Professional Accounting Ethics, Auditor Competence, Integrity, Professional Commitment, Audit Quality

Received: 20 Jan $2020 \quad$ C The Authors 2019

Revised: 28 Jan 2020 Published by Human Resource Management Academic Research Society (www.hrmars.com)

Accepted: 29 Jan 2020 This article is published under the Creative Commons Attribution (CC BY 4.0) license. Anyone may non-commercial purposes), subject to full attribution to the original publication and authors. The full terms of this license may be seen at: http://creativecommons.org/licences/by/4.0/legalcode

\section{Introduction}

Changes that occur nowadays related to audit quality could give an influence on the auditor profession. Technological development, service users who are increasingly aware of their importance and government regulations that have consequences for public accountability have changed the objectives, focus and approach of the audit regarding audit quality. Users of audited financial statements are free from material misstatement and their truth can be trusted so that it can be used as a basis for making decisions and in accordance with financial principles that apply in Indonesia (Taman et al., 2018). In accordance with the Government Internal Oversight Apparatus (APIP), one of the APIP is the Financial and Development Supervisory Agency (BPKP). BPKP is one of the government institutions that conduct internal oversight of financial management and national development accountability to support governance and corporations such as clean and effective BUMN/BUMD (BPKP, 2019). 
DeAngelo (1981) defines audit quality as an assessment carried out by the market where there is the possibility of the auditor making a discovery of a violation in the client's accounting system and its records. Audit quality of the public sector is an opportunity for a government auditor to find and report an institution or government. The audit of government institutions aims to ensure public accountability by the central/regional government and BUMN/BUMD (Sari and Lestari, 2018). According to data from the Financial Reporting Council (FRC) related to Audit Quality Inspection (AQI), KAP Big Four has a worse performance than the $2016 / 2017$ cycle. This is indicated by the fact that $25.5 \%$ of audits conducted by the Big Four KAP require improvement and $14.4 \%$ of audits are stopped to make improvements. Overall results show that $27 \%$ of Big Four KAPs need limited improvements, more than the 2016/2017 AQI cycle of $7 \%$. The FRC has determined that $90 \%$ of the target is needed for audit improvements due to a decline in audit quality this year. These results indicate that $73 \%$ obtained an acceptable standard that means that it indicates that there is concern about the level of trust in the auditor of audit quality.

Problems related to audit quality also occur in Indonesia. One of them is the Government Internal Oversight Apparatus (APIP). Sourced from detik.com (2019), the first problem is the position of APIP itself in an institution. The intervention of the Regional Secretary is very high on the results of APIP supervision because the position of the Regional APIP is generally under the Regional Secretary so that it is weakens the supervision of APIP. The second problem is the capability of APIP. Based on the Internal Audit Capability Model (IACM) index developed by BPKP, most of the APIPs are below level 1 and 2 until Quarter II of 2018. However, the minimum standards targeted by BPKP for the capabilities of APIP are at level 3 from level 5 as the highest level of the IACM Index. The third problem lies in the paradigm applied by APIP that auditors are watchdogs who act as reactive to problems that only focus on finding findings rather than looking at the actual root of the problems.

Another problem faced is that not all examiners have adequate quality in the sense that auditors who conduct audits do not all have functional auditor positions. Likewise, the number of activities or programs to be audited is not proportional to the number of auditors available. The condition of HR is also still a cause for concern because auditors with a background in accounting education are still very few (Kisnawati and Kartini, 2014). In addition, according to a source from detik.com, it was explained that one of BPKP's auditors, Triono, claimed to have received money from the joint audit and inspection audit budget at the Ministry of Education and Culture. Tomi pleaded guilty to receiving money in the activities of the teacher certification wasric (sergu) in 2013 at the Inspectorate IV of the Ministry of Education and Culture. The quote illustrates that the BPKP auditor did not apply the APIP code of ethics in carrying out his audit assignments.

Related to improving audit quality, there are studies that show factors that can affect audit quality. The results of research by Oraka and Okegbe (2015) and Widyanto et al. (2018) concluded that professional accounting ethics had a positive effect on audit quality. While the research results of Himawati et al., (2017) concluded that the ethics auditor had a negative and not significant effect on audit quality. Audit quality is also influenced by auditor competency factors. The results of Pandoyo's (2016), Siagian and Meutia (2016) research, and Halim et al. (2014) concluded that auditor competence had a positive effect on audit quality. In contrast to the results of research by Ningsih and Kiswanto (2019), the auditor's competence has a negative effect on APIP's audit quality. Another factor that influences audit quality is integrity. The results of research by Ningsih and Kiswanto (2019), Bouhawia et al. (2015), Himawati et al. (2017), Parasayu and Rohman (2014) and Kertarajasa et al. (2019) concluded that integrity has a positive effect on audit quality. In contrast to the results of research by Sihombing and Triyanto (2019) which states that integrity has a negative and not significant effect on audit quality.

The purpose of this study is to determine the effect of the implementation of professional accounting ethics, auditor competence, integrity and professional commitment to audit quality and to understand the effect of implementation auditor competencies and integration of audit quality that is moderated by professional commitment. 


\section{Literature review}

\subsection{Stewardship Theory}

Stewardship theory is a theory that describes situations in which managers are not motivated by individual goals but rather are aimed at their main outcome goals for the benefit of the organization, so this theory has a psychological and sociological basis that has been designed in which executives as stewards are motivated to act according to the principal's wishes. Referring to the theory of stewardship, steward behavior is collective; because stewards are guided by these behaviors organizational goals can be achieved. Experts related to stewardship theory assume that there is a very strong relationship between organizational success and principal satisfaction. Steward protects and maximizes shareholders through company performance. Successful Stewards can improve company performance so that stewards can satisfy most of the interests of shareholders who have been well served through the increased prosperity achieved by the organization. Therefore, pro-organization stewards are motivated to maximize company performance, in addition to being able to provide satisfaction to the interests of shareholders (Anton, 2010).

\subsection{Attribution Theory}

Attribution theory is an attempt to understand the causes behind the attitudes of other people's behavior or one's own behavior (Weiner, 1980). Attribution theory proposed by Robbin (2006) and Rahmi and Sovia (2017) explains that a person's behavior is caused by internal factors or external factors. Behavior caused by internal factors is behavior that is believed to be under control or originates from within an individual such as personality traits, motivation or abilities. Behavior caused by external factors is behavior as a result of external causes or originating from outside the individual self-such as equipment or social influence from others (Kusumastuti, 2012).

\section{Development of Hypotheses and Research Models}

\subsection{The Effect of Professional Accounting Ethics on Audit Quality}

A form of professionalism, especially in the fields of accounting and auditing, can show commitment to the quality of audits produced. Auditors, who have high norms and ethics in accordance with APIP audit standards, are able to produce good audit quality. The results of research by Oraka and Okegbe (2015) and Widyanto et al. (2018) concluded that professional accounting ethics had a positive effect on audit quality. If the auditor does not have good ethics and norms, it can damage public trust in the auditor profession and vice versa. Therefore, auditors are required to uphold ethics and norms and maintain professionalism in accordance with auditing standards and the APIP code of ethics (Parasayu and Rohman, 2014). Based on the description above, then the hypothesis can be formulated as follows:

\section{$\mathrm{H}_{1}$ : Professional Accounting Ethics has a significant effect on audit quality.}

\subsection{The Effect of Auditor Competence on Audit Quality}

Pandoyo (2016) said that an auditor must have good quality personally, knowledge and special expertise in his field. Competence is an auditor's expertise gained from knowledge and training. The results of research by Pandoyo (2016), Siagian and Meutia (2016), Widyanto et al. (2018), Sari and Lestari (2018), Shintya et al. (2016), Kertarajasa et al. (2019), Bouhawia et al. (2015) and Halim et al. (2014) concluded that auditor competence has a positive effect on audit quality. Every auditor must meet certain requirements to become a professional auditor. Auditors must be sued for competence. If he has a lot of knowledge in the field of audit and accounting, the auditor can find irregularities that occur so that high competence can improve the quality of audits produced by the auditor (Kertarajasa et al., 2019). Based on the description above, then the hypothesis can be formulated as follows:

$\mathrm{H}_{2}$ : Auditor competence has a significant effect on audit quality.

\subsection{The Effect of Integrity on Audit Quality}

According to Parasayu and Rohman (2014), integrity is a quality that can increase trust and as a guide for audit members to test decisions on their audit work in accordance with ethical standards. Integrity is a 
factor that influences audit quality. The results of research by Ningsih and Kiswanto (2019), Bouhawia et al. (2015), Himawati et al. (2017), Parasayu and Rohman (2014) and Kertarajasa et al. (2019) concluded that integrity has a positive effect on audit quality. Auditors perform audit tasks by upholding the value of integrity, and then the audit results will be of high quality. Integrity requires the auditor to carry out his audit duties by upholding the principle of honesty, not violating the principle of the agreed audit object boundaries and can defeat personal interests. Based on the description above, then the hypothesis can be formulated as follows:

$H_{3}$ : Integrity has a significant effect on audit quality.

\subsection{The Effect of Professional Commitment on Audit Quality}

According to Yetmar (2005) and Halim et al. (2014) said that high professional commitment is reflected in sensitivity to professional ethical issues to improve auditor competence. The existence of an audit engagement fosters professional commitment as an auditor who must meet the required competencies and conditions in providing services that have an impact on increasing public confidence and stakeholders. Professional commitment is an important element in the world of work because professional commitment is able to influence the success and performance of a person in his audit so that audit quality increases. Based on the description above, then the hypothesis can be formulated as follows:

$H_{5}$ : Professional commitment moderates the effect of auditor competence on audit quality.

\subsection{Professional Commitment Moderates the Effect of Auditor Competence on Audit Quality}

According to Yetmar (2005) and Halim et al. (2014) say that professional commitments are high reflected in sensitivity to professional ethical issues to improve competence auditor. The existence of an audit engagement grows professional commitment as an auditor who meets the required competencies and conditions in providing services that have an impact on increasing public and stakeholder trust. Professional commitment is an important element in the world of work because professional commitment is able to influence one's success and performance in the audit so that the audit quality increases. Based on the description above, it can be formulated hypothesis as follows:

$\mathrm{H}_{5}$ : Professional commitment moderates the effect of auditor competence on audit quality.

\subsection{Professional Commitment Moderates the Effect of Integrity on Audit Quality}

When professional commitment in applying the principle of high integrity, quality audits can be fulfilled. Professional commitment is a form of auditor's moral responsibility for what is deferred. Auditors who have high professional commitment are able to apply the principle of integrity that will improve the quality of the resulting audit. Therefore, professional commitment is able to strengthen the effect of integrity on audit quality. Based on the description above, then the hypothesis can be formulated as follows:

$H_{6}$ : Professional commitment moderates the effect of integrity on audit quality.

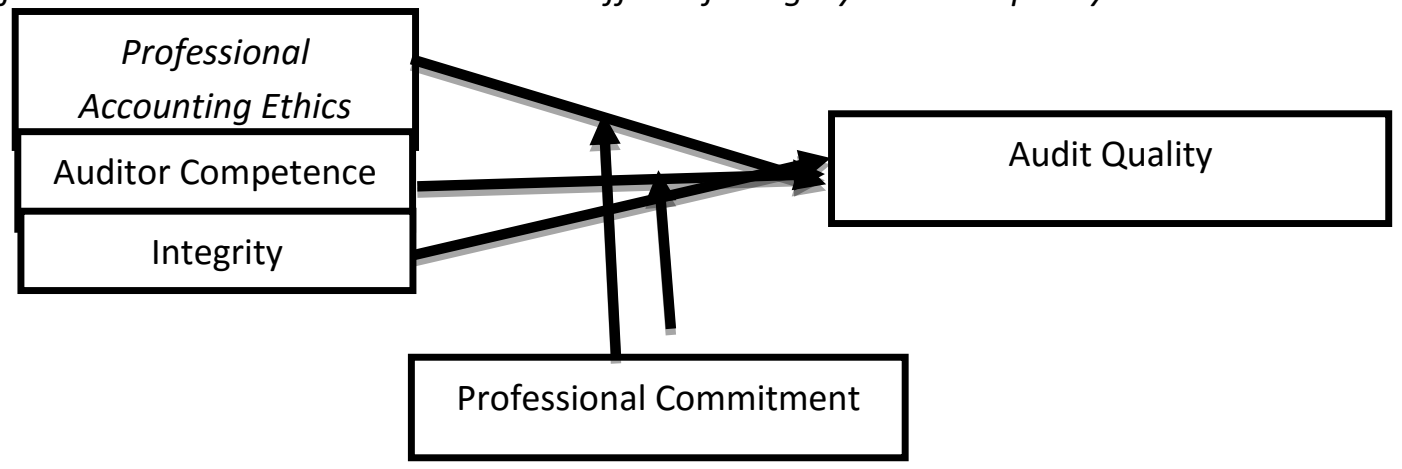

Figure 1. Conceptual Framework 


\section{Methodology of research}

The questionnaire was designed and compiled to facilitate respondents in understanding the questionnaire, so researchers can distribute the questionnaire to the real respondents namely auditors BPKP DKI Jakarta Province Representative. The number of questionnaires returned was 62 from 80 questionnaires. Hypotheses are tested using structural equation model (SEM) modeling by Smart PLS version 3.0. The dependent variable used in this study is audit quality. Audit quality is measured using research from Ika Sukriah et al. (2009). The independent variables in this study are professional accounting ethics, auditor competence and integrity. Professional accounting ethics was measured using research from Murtanto and Marini (2003). Auditor competence and integrity are measured using research from Ika Sukriah et al. (2009). The moderating variables used in this study are professional commitments adopted using research from Sri Trisnaningsih (2003). All variables contained in this study used a 5-point Likert scale with a total of 66 statements from 5 variables.

\section{Results}

This study has 62 respondents who work in BPKP DKI Jakarta Provincial Representatives. Respondents were asked to write demographic information in the questionnaire. The statistical results in this study indicate that 25 respondents with a percentage of $40 \%$ are female, $21 \%$ of respondents or numbered 13 respondents were male and the difference was 24 respondents (39\%) chose anonymous. Furthermore, respondents in the age category of respondents in this study were aged 20-29 years with a total of 13 respondents (21\%), 4 respondents (7\%) aged 30-39 years, 4 respondents (7\%) aged $40-49$ years, 11 respondents (18\%) aged $>50$ years and the difference of 30 respondents chose anonymous $(47 \%)$. Then, respondents who filled out the questionnaire with Diploma (D3) level were 6 respondents (10\%), 4 respondents (7\%) had Diploma (D4), 23 respondents (37\%) had Bachelor degree (S1), 5 respondents (8\% ) Postgraduate education (S2) and the difference in respondents choosing anonymous totaling 24 respondents (38\%). Finally, for the old category served in BPKP DKI Jakarta Provincial Representatives in this study as many as 13 respondents $(21 \%)$ for $<5$ years, 5 respondents (8\%) served for $5-10$ years, 1 respondent (2\%) served for $11-15$ years, 19 respondents (31\%) served for 15 years and the difference between respondents choosing anonymous was 24 respondents (38\%).

Table 1. Validity and Reliability Test

\begin{tabular}{cccc}
\hline $\mathrm{R}^{2}=0,792$ & & & \\
\hline Variable & AVE & Composite Reliability & Cronbach's Alpha \\
\hline I & 0,499 & 0,922 & 0,910 \\
AQ & 0,547 & 0,920 & 0,899 \\
AC & 0,580 & 0,924 & 0,908 \\
PC & 0,543 & 0,945 & 0,942 \\
PAE & 0,666 & 0,947 & 0,936 \\
\hline
\end{tabular}

Source: Processed Data

Table 1 shows the results of the validity and reliability test in this study about the acceptable level having a value of at least $60 \%$ used for the purposes of survey instruments (Malhotra, 2004). As can be seen in table 1 above, the construct reliability test is in the range of 0.899-0.942. These results prove the level of validity and reliability in the Structural Equation Modeling (SEM) model with the Partial Least Squares (PLS) technique used to test hypotheses and this requires a significance level of 0.05 or $5 \%$ for approval of acceptance or rejection hypothesis. This shows all the variables in the results of this study have a good reliability value of each construct and are declared valid. This study also processes in table 1 that $R^{2}$ $=0.792$ and appears the independent latent variable namely the professional accounting ethics (PAE) variable, auditor competence $(\mathrm{AC})$ and integrity $(\mathrm{I})$ and professional commitment as a moderating variable (PC) can describe the dependent latent variable namely audit quality variable (AQ) of $79.2 \%$ and the remaining $20.8 \%$ is explained by other factors outside of other studies such as religiosity, auditor education, observance of laws, auditor morality and auditor motivation. 
Table 2. Hypothesis Results Using Structural Equation Modeling

\begin{tabular}{|c|c|c|c|}
\hline Variable & Path Coefficients & T-Value & P-Value \\
\hline$P A E->A Q$ & 0,447 & 4,280 & 0,000 \\
\hline$A C \rightarrow A Q$ & $-0,141$ & 0,964 & 0,336 \\
\hline $\mathrm{I}->A Q$ & 0,674 & 4,975 & 0,000 \\
\hline$P C \rightarrow A Q$ & 0,120 & 0,823 & 0,411 \\
\hline$A C \rightarrow P C \rightarrow A Q$ & 0,134 & 0,817 & 0,415 \\
\hline $1->P C->A Q$ & $-0,384$ & 2,438 & 0,015 \\
\hline
\end{tabular}

Source: Processed Data

The results of testing this hypothesis use the structural equation modeling (SEM) model using smart PLS software version 3.0. Table 2 shows that professional accounting ethics (PAE, $t=4,280$ and $p$-value $=$ $0,000)$ and integrity $(I, t=4,975$ and $p$-value $=0,000)$ affect audit quality which means that HA1 and HA3 are accepted. Meanwhile, professional commitment moderates the influence of the relationship between integrity and audit quality $(\mathrm{I}-\mathrm{PC}, \mathrm{t}=2,438$ and $\mathrm{p}$-value $=0.015)$ which means that HA6 is accepted. The auditor's competence $(A C, t=0.964$ and $p$-value $=0.336)$ and professional commitment $(P C, t=0.823$ and p-value $=0.411$ ) do not affect audit quality which means that HA2 and HA4 are rejected. Finally, professional commitment does not moderate the effect of the relationship between auditor competence and audit quality (AC $>P C, t=0.817$ and $p$-value $=0.415$ ), which means HA5 is rejected.

Professional accounting ethics significantly influences audit quality. It can be said that auditors who have high norms and ethics in accordance with APIP audit standards, are able to produce good audit quality. If the auditor does not have good ethics and norms, it can damage public trust in the auditor profession and vice versa. Therefore, auditors are required to uphold ethics and norms and maintain professionalism in accordance with auditing standards and the APIP code of ethics. The results of this study are in line with research conducted by Oraka and Okegbe (2015), Parasayu and Rohman (2014), Kamil et al. (2011) and Enofe et al. (2015). The results of this study are also in line with the stewardship theory which explains that stewards are expected to uphold the ethics of accounting professionals so that they can achieve more effective and efficient management of state/regional budgets.

Another test result related to audit quality in this study is that auditor competence has no significant effect on audit quality. This is because competence is not the most important thing in conducting audit assignments so that auditors who have the expertise gained from knowledge and training do not affect the increase in audit quality produced by the government's internal auditors. The results of this study are in line with research conducted by Biri (2019) and Ningsih and Kiswanto (2019). However, the results of this study are not in line with the research conducted by Sari \& Lestari (2018). The results of this study are also not in line with the stewardship theory which explains that auditors, especially APIP, are required to exert all their competencies in carrying out their responsibilities for the benefit of the owner because the auditor acts as a steward for the principal.

As for the results of testing other hypotheses related to audit quality in this study, integrity has a significant effect on audit quality. That is due to the auditor must have integrity which includes an objective attitude, based on facts and not related to a particular ideology. Integrity is a factor that influences audit quality. Auditors perform audit tasks by upholding the value of integrity, and then the audit results will be of high quality. Integrity requires the auditor to carry out his audit duties by upholding the principle of honesty, not violating the principle of the agreed audit object boundaries and can defeat personal interests. The results of this study are in line with research conducted by Parasayu and Rohman (2014), Ningsih and Kiswanto (2019), Susilo and Widyastuti (2015), Kertarajasa et al. (2019) and Bouhawia et al. (2015).

Furthermore, the results of testing other hypotheses related to audit quality in this study are that professional commitment does not significantly influence audit quality. This is because the long time working as a government internal auditor is only seen as professionalism, not professional commitment. The auditor carries out audit assignments only as work demands and does not intend to serve the profession currently carried out by the government internal auditors. The results of this study are in line with research conducted by Salsabila (2017). However, the results of this study are not in line with Arifah 
and Romadhon (2015) that states that professional commitment has a significant effect on job satisfaction. This research is not supported by attribution theory that states that professional commitment is an internal factor behind the application of APIP's attitude in carrying out its duties towards audit quality.

Finally, the results of testing hypotheses related to audit quality in this study are professional commitments to moderate the relationship of integrity to audit quality. The results of this study are in line with attribution theory that states that this theory tries to understand the causes that occur in various events that it faces. This theory looks at and determines whether the actions taken by the auditor are caused internally or externally. Professional commitment is categorized as an internal attribution related to the integrity of APIP.

\section{Conclusions}

This study begins with the problem of auditor performance on the Big Four Public Accounting Firm and requires an improvement in audit quality due to a decreased audit quality assessment on the Big Four Public Accounting Firm. Problem related to audit quality is also experienced by government internal auditors. This is due to several factors such as the minimum standards set by the BPKP that have not been met by government internal auditors, auditor staff with accounting education backgrounds are still very few, auditors have not applied the APIP code of ethics and so forth. This study aims to determine the extent of the audit quality produced by the government's internal auditors at the Financial and Development Supervisory Agency of DKI Jakarta Province Representatives.

The results of this study indicate that professional accounting ethics and integrity significantly influence audit quality. Auditor competence and professional commitment do not significantly influence audit quality. The results of this study also indicate that professional commitment moderates the effect of the relationship between integrity and audit quality and negatively affects professional commitment and does not moderate the effect of the relationship between auditor competence and audit quality.

One limitation in this study is the number of questionnaires that have not been returned by respondents is quite large at 18 questionnaires. This is due to the busy schedule of auditors who are often outside the office in the context of audit assignments so that the auditor has not had time to fill out the questionnaires that have been distributed by researchers. In addition, the majority of respondents related to this study were aged 20-29 years with 13 people and more than 50 years with 11 people. However, respondents aged 30-39 years and 40-49 years were still very few with each numbering 4 people.

Suggestions for BPKP auditors DKI Jakarta Province Representatives are expected to be able to improve ethical principles in accordance with APIP standards in carrying out audit assignments and the auditor must also be responsible for any audit assignments performed by government internal auditors so that auditors continue to gain public trust. This research is expected for future research to be able to add other variables that can affect audit quality such as religiosity, auditor education, legal compliance, auditor morality and auditor motivation that can be used as research variables. Then, the next researcher needs to expand the research object and increase the number of respondents so that the conclusions from the results of further research can be judged to be more valid. In addition, future researchers must also pay attention to the questionnaire that will be used in future research so that the number of constructs is not dropped from the analysis too much.

\section{References}

1. Anton, F. X. (2010). Menuju Teori Stewardship Manajemen.

2. Arifah, D. A., \& Romadhon, C. (2015). Pengaruh Komitmen Organisasi, Komitmen Profesional dan Gaya Kepemimpinan terhadap Kepuasan Kerja dengan Motivasi sebagai Variabel Intervening. Conference in Business, Accounting and Management, 2(1), 357-369.

3. Biri, S. F. L. (2019). Pengaruh Kompetensi, Independensi, dan Fee Audit terhadap Kualitas Audit. Akuntansi Dewantara, 3(2), 1-14.

4. Bouhawia, M. S., Irianto, P. G., \& Baridwan, Z. (2015). The Effect of Working Experience , Integrity , Competence, and Organizational Commitment on Audit Quality (Survey State Owned Companies In Libya). IOSR Journal of Economics and Finance (IOSR-JEF), 6(4), 60-67. 
5. BPKP. (2019). Visi, Misi, Nilai dan Motto. Diakses 6 November 2019, dari http://www.bpkp.go.id/konten/2/Visi-Misi-dan-Nilai.bpkp

6. DeAngelo, L. E. (1981). Auditor size and audit quality. Journal of Accounting and Economics, 3(May), 183-199.

7. DetikNews. (2013). Auditor BPKP Akui Terima Duit dari Kemendikbud. Diakses 6 November, 2019, dari https://news.detik.com/berita/2314690/auditor-bpkp-akui-terima-duit-dari-kemendikbud.

8. Enofe, A. O., Edemenya, C. C., \& Osunbor, E. O. (2015). The Effect of Accounting Ethics on the Quality of Financial Reports of Nigeria Firms. Research Journal of Finance and Accounting, 6(12), 123-131.

9. Halim, A., Sutrisno, T., Rosidi, \& Achsin, M. (2014). Effect of Competence and Auditor Independence on Audit Quality with Audit Time Budget and Professional Commitment as a Moderation Variable. International Journal of Business and Management Invention, 3(6), 64-74.

10.Himawati, D., Mulatsih, \& Putri, F. (2017). Analisis Faktor-Faktor yang Mempengaruhi Kualitas Audit Internal pada Inspektorat Jenderal Kementerian Pekerjaan Umum dan Perumahan Rakyat. Forum Keuangan Dan Bisnis Indonesia, 6, 141-148.

11.Asosiasi Auditor Internal Pemerintah Indonesia. (2014). Kode Etik Auditor Intern Pemerintah Indonesia.

12.Kamil, I., Sukarmanto, E., \& Maemunah, M. (2011). Pengaruh Etika Auditor, Pengalaman Auditor dan Audit Fee terhadap Kualitas Audit Studi Empiris pada Kantor Akuntan Publik ( Kap ) di Kota Bandung. Prosiding Akuntansi, 783-790.

13.Kertarajasa, A. Y., Marwa, T., \& Wahyudi, T. (2019). The Effect of Competence, Experience, Independence, Due Professional Care, And Auditor Integrity on Audit Quality With Auditor Ethics As Moderating Variable. Journal of Accounting, Finance and Auditing Studies, 5(1), 80-99.

14.Kisnawati, B., \& Kartini, E. (n.d.). Dilema Auditor pada Sektor Pemerintah dalam Mewujudkan Kualitas Audit. 1-15.

15.Kusumastuti, N. R. (2012). Analisis Faktor-Faktor yang Berpengaruh terhadap Kecenderungan Kecurangan Akuntansi dengan Perilaku Tidak Etis sebagai Variabel Intervening. Universitas Diponegoro.

16. Malhotra, N. (2004). Marketing Research: An Applied Orientation $4^{\text {th }}$ ed. Pearson Prentice Hall Hopper Saddle River. NJ 07456.

17.Ningsih, Y., \& Kiswanto. (2019). Prinsip Perilaku APIP, Kualitas Audit dan Komitmen Profesional sebagai Moderating (Studi Empiris di BPKP Perwakilan Jawa Tengah). Jurnal Akuntansi Pajak, 7(1), 45-58.

18.Oraka, A. O., \& Okegbe, T. O. (2015). The Impact of Professional Accounting Ethics in Quality Assurance in Audit. International Journal of Academic Research in Business and Social Sciences, 5(8), 64-78.

19.Pandoyo. (2016). the Effect of Auditor Competence, Independence, Audit Experience, Organizational Culture and Leadership Against Auditor Professionalism and Its Implication on Audit Quality. International Journal of Advanced Research, 4(5), 1632-1646.

20.Parasayu, A., \& Rohman, A. (2014). Analisis Faktor-Faktor yang Mempengaruhi Kualitas Hasil Audit Internal (Studi Persepsi Aparat Intern Pemerintah Kota Surakarta dan Kabupaten Boyolali). Diponegoro Journal of Accounting, 3(2009), 1-10.

21.Rahmi, F., \& Sovia, A. (2017). Dampak Sistem Pengendalian Internal, Perilaku Tidak Etis dan Moralitas Manajemen terhadap Kecenderungan Kecurangan Akuntansi pada Perusahaan Developer di Pekanbaru. Jurnal Al-lqtishad, 13(1), 48-66.

22.Saefudin Achada. (2019). Strategi Penguatan Auditor Internal Pemerintah. Diakses 6 November 2019, dari https://news.detik.com/kolom/d-4618553/strategi-penguatan-auditor-internal-pemerintah.

23.Salsabila, L. (2017). Analysis of Premature Termination Factors on Audit Procedures with KAP Quality Control as Moderating Variable. Accounting Analysis Journal, 6(2), 207-218.

24.Sara White. (2018). AQI 2018: Decline in audit quality at Big Four firms | Accountancy Daily. Diakses 6 November 2019, dari https://www.accountancydaily.co/aqi-2018-decline-audit-quality-big-fourfirms

25.Sari, E. N., \& Lestari, S. (2018). Pengaruh Kompetensi dan Time Budget Pressure Terhadap Kualitas Audit Pada BPK RI Perwakilan Provinsi Sumatera Utara. Jurnal Riset Akuntansi Dan Keuangan, 6(1), 81-92.

26.Shintya, A., Nuryatno, M., \& Oktaviani, A. A. (2016). Pengaruh Kompetensi, Independensi dan Tekanan Anggaran Waktu terhadap Kualitas Audit. Seminar Nasional Cendekiawan, 1-19. 
27.Siagian, O., \& Meutia, I. (2016). Pengaruh Time Budget Pressure, Kompleksitas Tugas dan Kompetensi terhadap Kualitas Audit dengan Supervisi Audit sebagai Variabel Moderasi (Studi Empiris Pada Perwakilan BPKP Provinsi Sumatera Selatan). Akuntabilitas: Jurnal Penelitian Dan Pengembangan Akuntansi, 10(1), 55-78.

28.Sihombing, Y. A., \& Triyanto, D. N. (2019). Pengaruh Independensi, Objektivitas, Pengetahuan, Pengalaman Kerja, Integritas Terhadap Kualitas Audit (Studi Pada Inspektorat Provinsi Jawa Barat Tahun 2018). Jurnal Akuntansi, 9(2), 141-160.

29.Susilo, P. A., \& Widyastuti, T. (2015). Integritas, Objektivitas, Profesionalime Auditor dan Kualitas Audit di Kantor Akuntan Publik Jakarta Selatan. Jurnal Riset Akuntansi Dan Perpajakan, 2(1), 65-77.

30.Taman, A., Wijayanto, P. A., \& Rachmawati, E. (2018). Kualitas Audit Auditor Internal Pemerintah: Kompetensi, Independensi dan Profesionalisme. Jurnal Akuntansi, Ekonomi Dan Manajemen Bisnis, 6(1), 74-83.

31.Velury, G. D. K. U. (2005). The Impact of Managerial Ownership on the Likelihood of Provision of High-Quality Auditing Services. Review of Accounting and Finance, 4(2), 86-106.

32.Weiner, B. (1980). A Cognitive (Attribution) -Emotion-Action Model of Motivated Behavior: An Analysis of Judgments of Help-Giving. Journal of Personality and Social Psychology 1, 39(2), 186-200.

33.Widyanto, M. L., Kwarto, F., \& Kurniawati, S. (2018). Pengaruh Kompetensi, Etika dan Pengalaman Kerja terhadap Kualitas Auditor Internal. Profita: Komunikasi Ilmiah Akuntansi Dan Perpajakan, 11(2), 165182. 